\title{
ESTETIKA MATEMATIS MOTIF SONGKET PADA ANYAMAN MENDONG TASIKMALAYA
}

\author{
Fitriani Muldiana ${ }^{1 *}$, Shofa Laelatul Mukaromah ${ }^{2}$, Neng Ani Karleni $^{3}$, Nani Ratnaningsih ${ }^{4}$ \\ 1,2,3,4 Jurusan Pendidikan Matematika, Universitas Siliwangi, Tasikmalaya 46115, Indonesia \\ *Penulis Korespondensi.Email: pipit.muldiana@gmail.com
}

\begin{abstract}
Abstrak
Matematika merupakan ide yang penuh teka-teki dan menawan. Matematika juga dapat didefinisikan dalam konteks pola. Hal tersebut karena matematika berisikan pola, struktur dan penggambaran suatu objek yang tumbuh dan berakar dari kehidupan nyata. Struktur atau pola tersebut yang disusun secara sistematis akan menghasilkan sebuah karya, benda bahkan kesepakatan. Matematika kehidupan dan matematika pada pembelajaran sekolah dapat digabungkan dengan kajian estetika guna mencapai pembelajaran kontekstual. Penelitian ini menggunakan penelitian kualitatif dengan pendekatan etnografi. Tujuan dari penelitian ini adalah untuk mengungkap nilai estetik dan konsep matematis pada pola anyaman mendong dengan motif Songket. Tempat yang dilakukan pada penelitian ini yaitu di Kampung Babakan Cikawung, Kelurahan Margabakti, Kecamatan Cibeureum Awipari Kabupaten Tasikmalaya. Penelitian ini melibatkan tiga subjek. Teknik pengumpulan data yang dilakukan yaitu melalui wawancara tidak terstruktur, observasi, dokumentasi dan kajian literatur. Wawancara tidak terstruktur digunakan untuk menanyakan kerajinan mendong dan proses dibuatnya anyaman mending dengan motif Songket. Observasi atau pengamatan dilakukan untuk mencari konsep matematis dan nilai estetika matematis dengan kajian estetika teori Thomas Aquinas. Hasil penelitian menunjukkan bahwa terdapat estetika matematis dengan mengkaji teori Thomas Aquinas. Konsep matematis yang terkandung dalam motif songket pada anyaman meliputi pola yang berulang 1-2-3-4 dan 4-3-2-1, konsep geometris seperti garis sejajar, pencerminan (refleksi), kekongruenan, dan bentuk bangun datar belah ketupat.
\end{abstract}

Kata Kunci: Estetika Matematis; Motif Songket; Anyaman; Mendong

\begin{abstract}
Mathematics is an enigmatic and captivating idea. Mathematics can also be defined in the context of patterns. This is because mathematics contains patterns, structures, and depictions of an object that grows and is rooted in real life. The structure or pattern that is arranged systematically will produce work, objects, and even an agreement. Life mathematics and mathematics in school learning can be combined with aesthetic studies to achieve contextual learning. This study uses qualitative research with an ethnographic approach. The purpose of this study was to reveal the aesthetic value and mathematical concepts of the mendong woven pattern with the songket motif. The location of this research is Babakan Cikawung Village, Margabakti Village, Cibeureum Awipari District, Tasikmalaya Regency. This study involved 3 subjects. Data collection techniques were carried out through unstructured interviews, observation, documentation, and literature review. Unstructured interviews were used to ask about the craft of mendong and the process of making mending weave with songket motifs. Observations or observations are made to find mathematical concepts and mathematical aesthetic values by studying the aesthetics of Thomas Aquinas' theory. The results of the research are mathematical aesthetics by examining the theory of Thomas Aquinas. Mathematical concepts such as repeating patterns 1-2-3-4 and 4-3-2-1, geometric concepts such as parallel lines, reflection, congruence, and rhombus flat shapes.
\end{abstract}

Keywords: Mathematical Aesthetics; Songket Motifs; Woven; Mendong 


\section{Pendahuluan}

Indonesia merupakan negara kaya akan warisan budaya. Kebudayaan tersebut dapat meliputi tarian, busan, bahasa, kerajinan tangan dan lain-lain. Budaya adalah keseluruhan gagasan dan karya manusia yang harus dibiasakan dengan belajar serta keseluruhan dari hasil budi pekerti [1]. Setiap manusia pasti memiliki kemampuan untuk menciptakan suatu karya dari hasil tangannya sendiri. Hal tersebut dapat disebut dengan kerajinan tangan. Di Indonesia setiap kerajinan tangan daerah mempunyai ciri khas masing-masing. Ciri khas tersebut dipengaruhi oleh potensi alam dan sumber daya manusia yang ada. Beberapa Kerajinan di Indonesia terbuat dari berbagai macam bahan diantaranya rotan, bambu, pandan, dan lainnya [2]. Kemampuan menciptakan suatu karya dapat berupa hasil dari proses belajar yang dilakukan ataupun keterampilan yang diwariskan secara turuntemurun. Salah satu keterampilan yang dapat diwariskan secara turun temurun agar tetap terjaga kelestariannya di masyarakat adalah menganyam. Menganyam diartikan sebagai mengatur (bilah, daun pandan, dan sebagainya) tindih-menindih dan silang-menyilang (seperti pembuatan tikar dan bakul)[3].

Banyak suku di Indonesia yang masih bertahan dengan memegang teguh serta tetap melestarikan ajaran nenek moyangnya, terutama dalam kegiatan menganyam. Selain melestarikan warisan nenek moyang, hasil dari kegiatan menganyam atau biasa yang disebut anyaman dapat bernilai ekonomis dan benilai guna tinggi. Dalam kehidupan sehari-hari, masyarakat suku Sunda tidak akan terlepas dari aktivitas menaksir, mengukur dan membuat pola [4]. Konsep-konsep tersebut tertanam dan membudaya dalam masyarakat setempat. Salah satu suku tersebut yaitu masyarakat suku Sunda yakni masyarakat Kampung Babakan Cikawung, Kelurahan Margabakti, Kecamatan Cibeureum, Kabupaten Tasikmalaya. Anyaman Awipari terkenal dengan anyaman yang berbahan dasar mendong. Anyaman tersebut dibuat dengan alat tradisonal dengan nama ATBM (Alat Tenun Bukan Mesin). Proses menganyam anyaman apabila dilihat dari segi matematikanya dan estetikanya akan membentuk pola-pola unik, seperti pada anyaman motif cucuk belut, motif sorban, motif bilik, motif Songket dan lain-lain.

Menurut pemilik perusahaan penghasil kerajinan mendong yaitu 2 Saudara, di Awipari terkenal sebagai penghasil kerajinan tikar dengan berbagai motif. Ada sekitar 70 orang karyawan dan 5 orang karyawan celup dengan total 75 orang karyawan. Karyawan tersebut adalah warga asli dari daerah tersebut dan memiliki ATBM masing-masing. Bahan baku dan benang disediakan oleh perusahaan.

Pengrajin dapat membuat 1-2 tikar mendong dalam kurun waktu satu hari dengan motif yang mudah. Pekerjaan menenun diteruskan turun temurun. Pengrajin membuat anyaman mendong tersebut memperhatikan pola dengan menghitung pola agar motif yang dihasilkan sesuai. Begitu pun dengan penghanian (penyusun benang) mereka dapat menghasilkan 2-3 gulungan benang dengan pencampuran atau gradasi warna yang unik sepanjang 20 meter secara manual dalam satu hari. Penyusun benang mempunyai rumusan tersendiri dalam penggradasian warna dengan mengukur panjang benang tenun penuh konsentrasi tinggi. Karena estetika atau keindahan bisa terlihat dari warna-warna yang cemerlang.

Matematika merupakan ide yang penuh teka-teki dan menawan [5]. Hal tersebut karena matematika berisikan pola, struktur dan penggambaran suatu objek yang tumbuh dan berakar dari kehidupan nyata. Struktur atau pola tersebut yang disusun secara sistematis akan menghasilkan sebuah karya, benda bahkan kesepakatan. Estetika pada prinsipnya adalah mengkaji suatu objek keindahan, baik keindahan yang diciptakan Tuhan maupun keindahan yang diciptakan manusia. Karya merupakan hasil dari aktivitas berpikir manusia dan dituangkan dalam wujud objek atau benda, dalam proses pembuatannya dibutuhkan olah pikir disertai penyatuan unsur-unsur lainnya sehingga membentuk sebuah karya dengan konsep dan pola yang terstruktur. Pola ini membentuk objek menjadi sebuah karya bernilai estetis, dan kemampuan menangkap pola itu merupakan esensi dari matematika [6].

Dalam dunia pendidikan sangat penting untuk menerapkan pembelajaran kontekstual, terutama dalam pembelajaran matematika. Materi pelajaran akan tambah berarti jika siswa mempelajari materi pelajaran yang disajikan melalui konteks kehidupan mereka, sehingga menyenangkan bagi siswa. 
Dengan demikian siswa akan bekerja keras untuk mencapai tujuan pembelajaran. Pembelajaran kontekstual akan menciptakan ruang kelas yang di dalamnya siswa akan menjadi peserta aktif bukan hanya pengamat yang pasif, dan bertanggung jawab terhadap belajarnya [7]. matematika dianggap sebagai ilmu pengetahuan yang sempurna dengan kebenaran yang objektif dan dirasakan jauh dari realitas kehidupan sehari-hari [8].

Menurut NCTM bahkan deskripsi sangat penting tentang apa artinya untuk melakukan matematika dapat didefinisikan dalam konteks pola, "matematikawan mengamati pola; mereka menduga, tes, mendiskusikan, dengan kata-kata, dan generalisasi pola-pola ini”. pola-pola estetika tersebut terdapat pada karya yang mana dapat memahami dimensi estetika matematis dalam pembelajaran [9]. Hal ini sejalan dengan pendapat Brown bahwa pembelajaran dengan memahami estetika matematis dapat menafsirkan pengajaran yang menghasilkan karya kreatif [10]. Kemudian estetika matematis teori Dewey dalam fotografi yang telah dilakukan oleh Meier juga berguna untuk medapatkan pengalaman praktis siswa, membuat berpikir kreatif tentang ide-ide baru, meningkatnya persepsi siswa tentang matematika, mempelajari konsep matematika dengan objek nyata, menganalisis gambar konkret dengan konsep matematika[11].

Estetika berasal dari Bahasa Yunani yaitu aisthetica dan aisthesis. Aesthetica adalah segala sesuatu yang dapat diserap oleh panca indera, sedangkan aisthesis adalah persepsi inderawi [12]. Estetika merupakan kajian tentang segala sesuatu yang berkaitan dengan keindahan. Suatu keindahan memenuhi tiga persyaratan berdasarkan teori Thomas Aquinas sebagai berikut; (1) Integrity or Perfection, yaitu keutuhan, kesempurnaan, atau keadaan yg menunjukkan kesatuan yg utuh dan lengkap segalanya serta tidak cacat maupun bercela; (2) Proportion or Harmony, yaitu perimbangan, perbandingan atau keserasian; dan (3) Brightness or Clarity (Kecemerlangan atau Kejelasan), yaitu berwarna cemerlang atau terang [13].

Kembali pada gagasan utama penelitian ini yaitu mengungkap nilai estetika dan konsep matematis pada anyaman mendong motif Songket pada pengrajin mendong Awipari Kabupaten Tasikmalaya. Ayamanan mendong merupakan kerajinan tradisonal yang sangat indah dan disenangi oleh masyarajat karena nilai estetika dan motif dari anyaman mendong tersebut. Di dunia seni, dapat dijumpai orang membuat sebuah karya seni dengan menggunakan konsep matematika dalam menyempurnakan hasil karyanya, seperti konsep bidang, perbandingan, dan geometri. Seorang ahli di dunia matematika yang mengaplikasikan keilmuannya, dapat menghasilkan sebuah objek sebagai hasil karya yang dapat dinikmati keindahannya. Hal ini menunjukkan bahwa matematika dan seni memiliki hubungan yang erat karena merupakan aktivitas dimana keduanya saling mendukung untuk terciptanya sebuah karya seni yang indah [6]. Hal tersebut relevan dengan penelitian Hidayat et al [9] yang menunjukan bahwa terdapat pola matematika 1-3-2- 4-2-3-1-4-2-3-1-3-2-4, dimana pola tersebut menghasilkan keindahan atau estetika pada motif cucuk belut. Injakan 4, dan dengan pola injakannya itu 12341234. Apabila bilihat dari konsep geometris menghasilkan bentuk segitiga sederhana. Sejalan dengan penelitian tersebut pengungkapan nilai estetika dari aktivitas fotografi dengan teori estetika Dewey [11] mengenalkan konsep dasar matematika seperti pada foto daun yang diambil salah satu siswanya. Foto tersebut mengandung simetris atau refleksi, memahami bentuk daun (geometri) dan kontruksi, teori bilangan, aritmatika, pola Fibonacci/rasio emas. Selain itu, menurut [14] estetika motif atau pola pada payung geulis mempunyai konsep geometri seperti translasi, refleksi, simetri, rotasi dan kekongruenan.

Dicetuskan motif Songket ini menurut Yayat karena hasil modifikasi dan diskusi dengan para pengrajin anyaman lainnya. Awalnya hanya anyaman kepang dari mendong yang dibuat tikar, namun seiring berjalannya waktu dapat menghasilkan motif-motif baru seperti motif Songket. Ide tersebut didapatkan dari aspek permintaan pasar, alam sekitar dan pola-pola dari sarung.

Dilihat dari pola dan motif pada anyaman mendong Tasikmalaya yang indah, motif Songket memiliki makna tersendiri bagaimana upaya manusia dapat memanfaatkan mendong sebagai hasil karya yang bernilai estetis. Pembuatan karya seni ini membutuhkan proses yang panjang dengan menggunakan teknik, prosedur dan pola-pola tertentu. Pola-pola tersebut berkaitan dengan konsep matematika. Banyak hal dari anyaman mendong yang perlu diteliti dan dikaji terutama dari segi 
estetikanya dan konsep matematika yaitu tentang bentuk dan pola yang terdapat pada anyaman tersebut. Hal ini dapat memperlihatkan hubungan timbal alik antara matematika dan budaya, teruatam konsep-konsep matematis dan estetikanya yang berhubungan langsung dengan kerajinan anyaman mendong. Sehinga dapat dimanfaatkan dalam upaya peningkatan kualitas pembelajaran matematika di sekolah. Dengan hal tersebut perlu diungkap nilai estetika dan konsep matematika pada anyaman mendong motif songket.

\section{Metode Penelitian}

Pada penelitian ini, digunakan pendekatan kualitatif karena permasalahan yang diteliti kompleks, holistik, dinamis dan penuh makna sehingga tidak mungkin data yang diperoleh pada situasi sosial tersebut didapatkan dengan pendekatan kuantitatif yang menggunakan instrumen seperti tes, penyebaran angket atau kuesioner untuk memperoleh datanya. Selain itu penulis bermaksud memahami situasi sosial secara mendalam. Menurut Wijaya [14] penelitian kualitatif adalah metode penelitian yang berlandaskan pada filsafat postpositivisme yang menekankan pada cara berpikir induktif yang menghasilkan data deskriptif, tidak berupa prosedur statistika yang luarannya berupa simpulan makna yang mendalam dari sekumpulan generalisasi.

Penelitian ini menggunakan pendekatan etnografi. Tujuan dari penelitian ini adalah untuk mengungkap nilai estetik dan konsep matematis pada pola anyaman mendong dengan motif Songket. Etnografi adalah studi kualitatif terhadap diri individu atau sekelompok dengan tujuan mendeskripsikan karakteristik kultural lebih mendalam secara sistematis dalam ruang dan waktu mereka sendiri [15].

Subjek yang diteliti relatif terbatas, namun variabel-variabel dan fokus yang diteliti sangat luas dimensinya. Penelitian ini melibatkan tiga subjek yaitu, Bapak Yayat sebagai pemilik anyaman mendong, Bapak Ujang sebagai pemihani (pemggulung) benang dan Ibu Yani sebagai pengrajin anyaman mendong. Penelitian ini dilakukan di Kampung Babakan Cikawung, Kelurahan Margabakti, Kecamatan Cibeureum Kabupaten Tasikmalaya. Penelitian ini dilakukan selama dua hari dengan hari pertama studi lapangan dan hari kedua dilakukan pengambilan data di lapangan. Peneliti yang terlibat ada 3 orang yang mempunyai tugas masing-masing yakni mewawancara narasumber, mengobservasi anyaman dan kegiatan pembuatan anyaman, dan mendokumentasi kegiatan.

Teknik pengumpulan data pada penelitian ini yaitu melalui wawancara tidak terstruktur, observasi, dokumentasi dan kajian literatur untuk mengungkap konsep matematis yang terdapat pada anyaman mendong. Wawancara tidak terstruktur digunakan untuk menanyakan sejarah kerajinan mendong dan proses dibuatnya anyaman mendong. Kegiatan wawancara dilakukan kepada 3 narasumber dengan cara direkam. Observasi atau pengamatan dilakukan untuk mencari konsep matematis dan nilai estetika matematis dengan kajian estetika teori Thomas Aquinas yang meliputi integrity for perfection (keutuhan, kesempurnaan, keadaan yang menunjukan kesatuan yang utuh dan lengkap segalanya), proportion of harmony (perimbangan, perbandingan atau keserasian), brightness or clarity (warna cemerlang atau terang) dari anyaman tersebut dan mencari hubungan nilai estetika matematis pada anyaman tersebut. Dokumentasi diperlukan untuk mengambil foto kegiatan pembuatan anyaman dan produk anyaman sebagai catatan lapangan. Kajian literatur digunakan untuk mencari tambahan data sebagai pelengkap data dalam kegiatan lapangan. Keabsahan data pada penelitian ini menggunakan triangluasi data dengan bersumber tiga subjek dan tiga kegiatan pengambilan data yaitu wawancara tidak terstruktur, observasi dan dokumentasi.

Data yang dikumpulkan dari wawancara, observasi dan dokumentasi kemudian dianalisis melalui tiga tahap yaitu (1) reduksi data merupakan proses pemilihan, pemusatan perhatian pada penyederhanaan, pengabstrakan, transfomasi data kasar yang muncul dari catatan-catatan lapangan [16] (2) penyajian data adalah tahap untuk memperoleh gambaran secara umum pada penelitian yang dapat diolah. Gambaran umum yang dimaksud adalah mengumpulkan data-data yang semuanya dirancang guna menggabungkan informasi yang disusun dalam bentuk yang padu. ; dan (3) penarikan kesimpulan atau verifikasi adalah tahap penarikan kesimpulan data yang telah dikumpulkan melalui penelitian. 


\section{Hasil dan Pembahasan}

Anyaman mendong motif Songket sebagai sebuah hasil karya manusia memiliki nilai estetika dilihat dari pola-polanya yang tersusun (gambar 1). Motif tikar Songket ini dicetuskan langsung oleh pengrajin itu sendiri dan motif ini hasil dari pemikirian kreatif dari seorang pengrajin. Asal mula adanya motif atau pola Songket ini pengrajin terinsfirasi dari melihat kerajinan-kerjainan orang lain seperti ukiran batik tas atau motif dalam pakaian dan akhirnya pengrajin mengaplikasikan ide tersebut untuk diterapkan pada anyaman mendong.

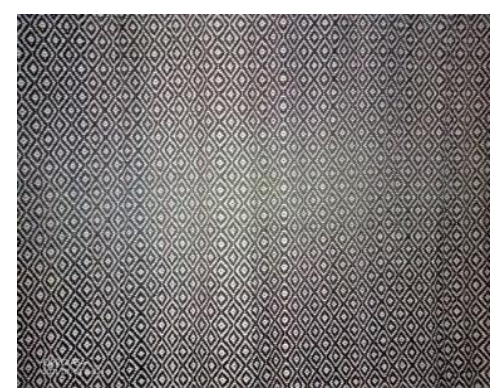

Gambar 1. Tikar Motif Songket

Dalam penerapan motif tersebut pengrajin juga harus memikirkan bagaiamana rumus yang harus diterapkan ke dalam anyaman, sehingga membentuk seperti belah ketupat dan akhirnya pengrajin memberikan nama pada bentuk tersebut dengan nama anyaman atau pola Songket. Waktu dalam pembuatan pola Songket ini menghabiskan waktu standarnya yaitu 2 hari dan menghasilkan tikar 5 meter dengan ukuran 60 x $5 \mathrm{~cm}$ per hari. Jadi dalam 2 hari menghasilkan 10 meter.

Dari hasil penelitian dan pengamatan yang telah penulis lakukan terdapat estetika matematis dari hasil karya anyaman mendong dari masyarakat Cibeureum, Tasikmalaya. Table 1 menyajikan kajian estetika matematis yang terdapat pada anyaman mendong motif Songket.

Tabel 1. Estetika Matematis pada Anyaman Mendong Motif Songket

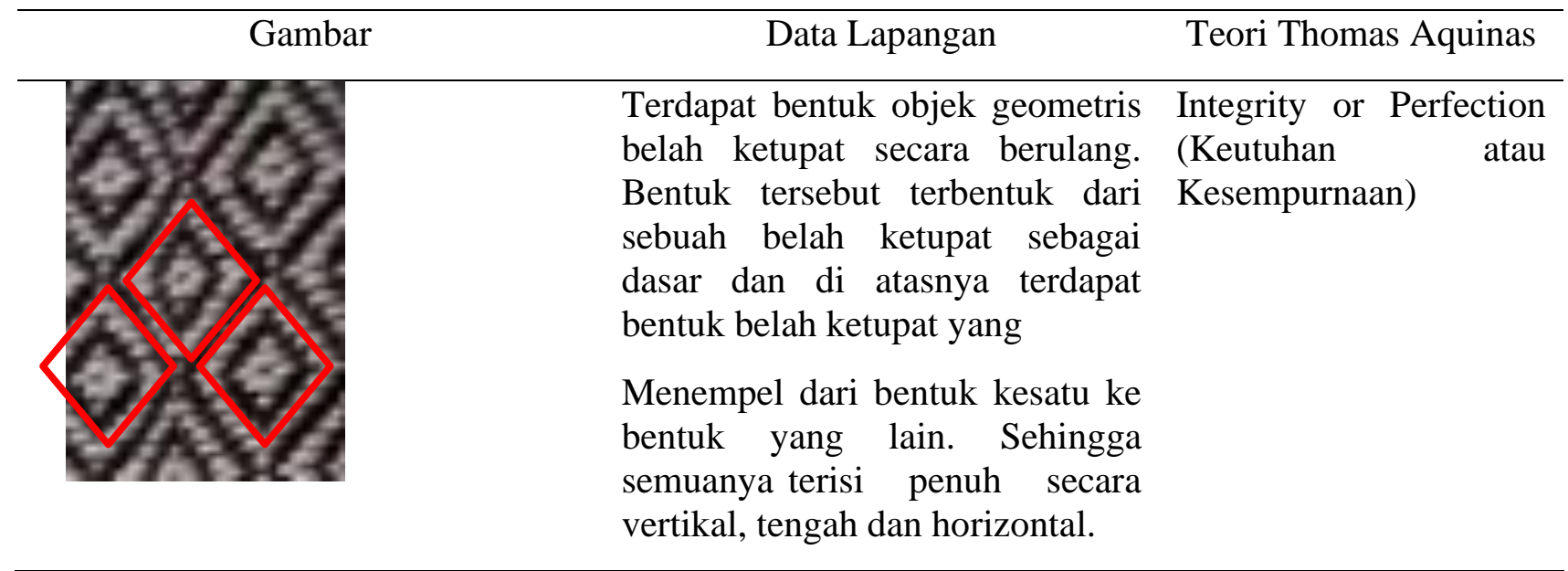



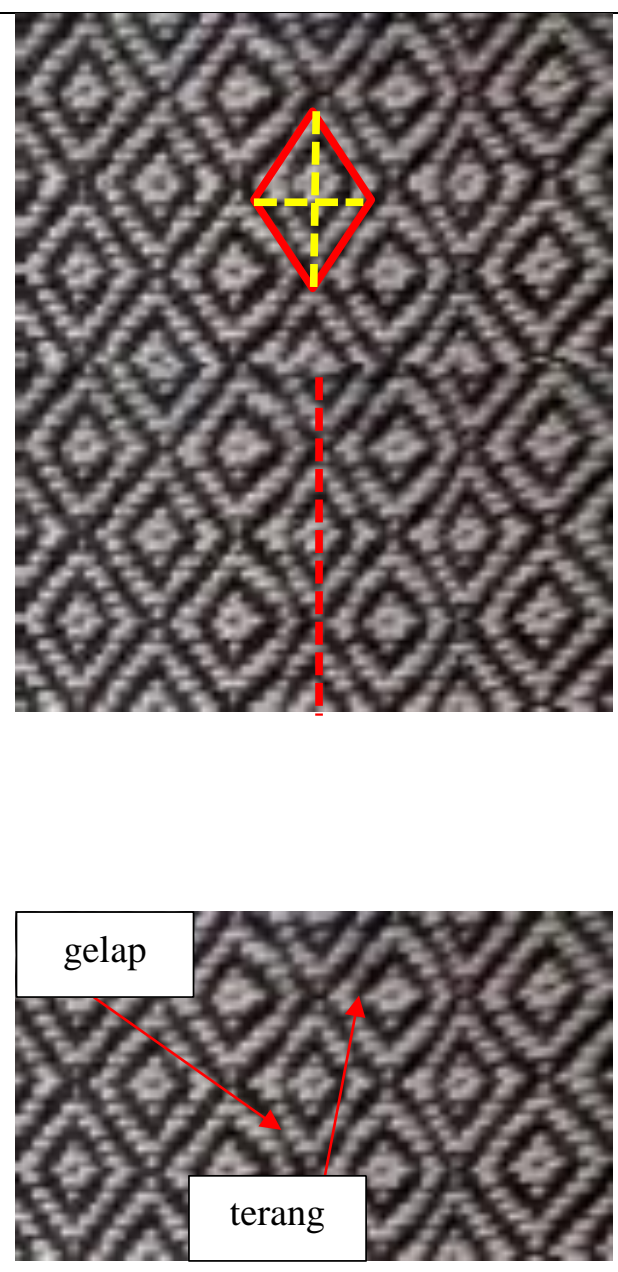

Memiliki proporsi yang simetris antara bentuk yang satu dengan bentuk yang lain. Pada bagian atas pola dan bawah pola. Apabila dilihat dari proses pembuatan polanya, mendong dianyam dengan rumus $1-2-3-4$

sebanyak dua kali. Kemudian menganyam dengan pola mundur yaitu 4- 3-2-1 sebanyak

kali. Sehingga terbentuk geometris belah ketupat yang simetris. Bentuk beleh ketupatnya pun kongruen yang artinya bentuk satu dengna yang lain

ukurannya sama.

Dari tikar dengan motif Songket tersebut pewarnaan menggunakan konsep gelap dan terang. Misalnya apabila warna dasar gelap, maka warna mendongnya akan terang. Hal ini akan mempengaruhi hasil akhir dari anyaman tersebut. Pewarnaan disesuaikan dengan permintaan pasar, namun agar menjaga keindahannya digunakan konsep gelap-terang dengan memperhatikan komposisi warna.
Proportion or Harmony

(Perimbangan atau

Keserasian)

Brightness or Clarity (Kecemerlangan atau Kejelasan)

Kajian estetika pada anyaman mendong motif songket relevan dengan penelitian Nur [6] yang berjudul Estetika Matematis pada Seni Ukir Jepara, bahwa terdapat estetika matematis pada hasil karya seni ukir Jepara. Keutuhan atau Kesempurnaan terdapat pada bentuk relung ukiran kayu sebagai dasar dan di atasnya terdapat relung berulang-ulang. Kemudian perimbangan atau keserasian dalam seni ukir Jepara tersebut yaitu ukiran meimiliki proporsi yang simetris antara ukiran bawah dan atas. Lalu kecemerlangan dan kejelasan dalam seni ukir Jepara memiliki gradasi warna halus antara putih dan coklat dengan dominan coklat. Didukung juga dengan penelitian Rosadi [17] yang mengungkapkan bahwa estetika seni mengandung komposisi bentuk seperti garis (garis vertikal, horizontal dan garis diagonal). Bentuk seperti bentuk dua atau tiga dimensi yang lebih kompleks seperti persegi panjang, belah ketupat, bentuk melengkung, volume dan lain-lain. Hal tersebut ada hubungannya dengan konsep matematis yang sering dipelajari di sekolah yakni bentuk geometris dan transformasi.

Dalam pembuatan proses anyaman mendong motif Songket terdapat beberapa langkah yang dilakukan oleh pengrajin. Adapun proses yang dilakukan pengarajin ketika membuat anyaman mendong diantaranya adalah memilih bahan baku (mendong). Dalam memilih mendong ini, pengrajin dapat menggunakan mendong dengan warna natural (belum di beri warna) atau dengan mendong yang sudah di beri warna yang sering di kenal dengan istilah pencelupan atau pemeberian warna pada mendong [18]. Untuk pemberian warna itu sendiri tergantung keinginan dari pasar atau dari pengrajin sendiri yang memodifikasi, untuk bahan baku warna (pewarna) yang ada di pasar atau 
di toko biasanya hanya terdapat warna hijau, merah dan ungu apabila pasar menginginkan warna yang lain atau pengrajin menginginkan warna yang lain, maka harus ada pencampuran warna dari beberpa warna yang lain.

Hal sederhana dari fungsi warna dalam sebuah kerajinan adalah memberikan nilai estetika, keindahan, serta menghilangkan kesan kusam dan terlalu polos. Sebuah kerajinan yang didesain dengan menggunakan warna-warna tertentu, akan terlihat jauh lebih indah daripada sebuah kerajinan yang tidak diberi warna. Umumnya pilihan warna objek akan disesuaikan oleh pengrajin itu sendiri. Dalam pemilihan warna ini pengrajin menggunakan prinsip gelap terang.

Warna merupakan salah satu elemen yang paling ekspresif karena kualitasnya dapat mempengaruhi seseorang secara emosional. Warna memberikan ekspresi kepada pikiran dan jiwa manusia yang melihatnya. Sebab itu warna juga sedikit banyak menentukan karakter [19] Pada dasarnya estetika memiliki manfaat penting bagi manusia. Selain untuk ilmu pengetahuan, keberadaan estetika juga membuat seseorang dapat menikmati seni dan keindahan.

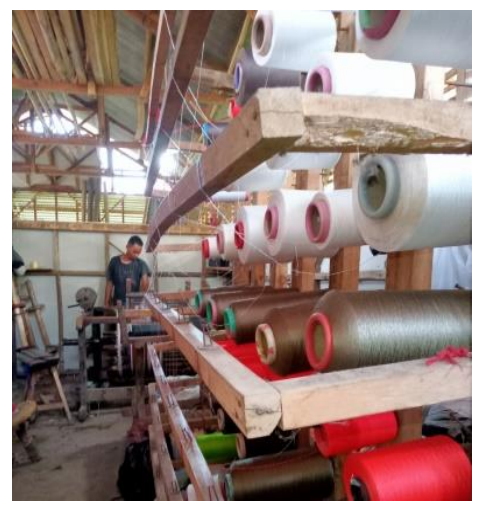

Gambar 2. Proses Penyusunan Benang (Mihani)

Proses selanjutnya, yang di lakukan pengrajin adalah pemilihan benang yang akan di pasang di ATBM (Alat Tenun Bukan Mesin) (lihat Gambar 2, Gambar 3, Gambar 4). Proses penyusunan benang ini di lakukan oleh karyawan yang sudah mahir dalam melakukan ini karena proses pemasangan benang ini adalah kuncinya untuk membuat suatu pola dan yang penulis teliti di sini yaitu pola Songket, proses pemasangan benang ini sering di kenal dengan istilah mihane atau mihani. Benang merupakan unsur motif hias yang terdapat pada sebuah kerajinan,keragaman warna yang terkandung dalam benang merupakan sebuah keindahan atau estetika dalam sebuah kerjinan. Varian benang kecil ataupun benang besar dalam sebuah kerajinan dapat menentukan sesuai atau tidaknya dalam motif tersebut serta hasil yang di dapat akan mementukan sebuah keindahan dari kerajinan tersebut.

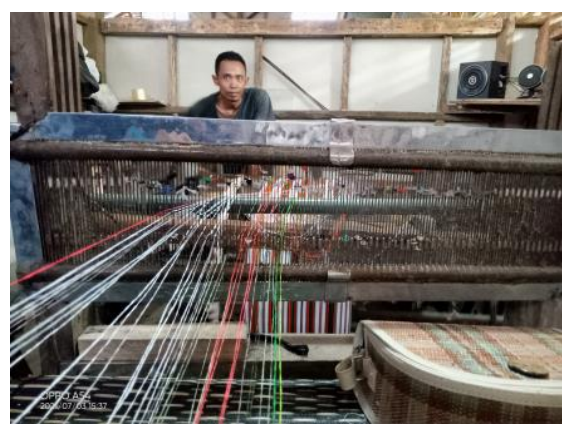

Gambar 3. Proses Penyusunan Benang (Mihani) 2 


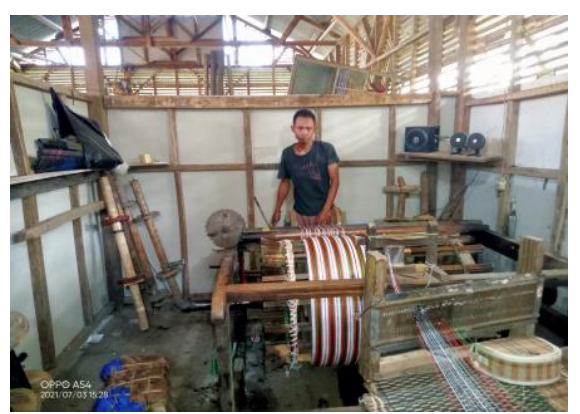

Gambar 4. Proses Penyusunan Benang (Mihani) 3

Berdasarkan jenis ATBM (Alat Tenun Bukan Mesin), dibagi menjadi dua yaitu ATBM kecil yang memiliki injakan 4 serta sisir 4 dan ATBM besar yang memiliki injakan 2 serta sisir 2. Pada motif Songket, jenis ATBM yang digunakan agar terbentuk keindahan dari hasil ssebuah karya, maka pengrajin memilih ATBM kecil dengan injakan 4 dan sisir 4. Selanjutnya yaitu proses pemilihan ATBM (Alat Tenun Bukan Mesin), proses pemilihan ini dilakukan sesuai dengan pola yang akan di buat oleh pengrajin, karena penulis mengambil motif Songket jadi ATBM yang di pilih yaitu menggunakan ATBM yang kecil serta injakan nya berjumlah 4 apabila injakan nya berjumlah 4 maka sisir yang di atasnya juga berjumlah 4 .

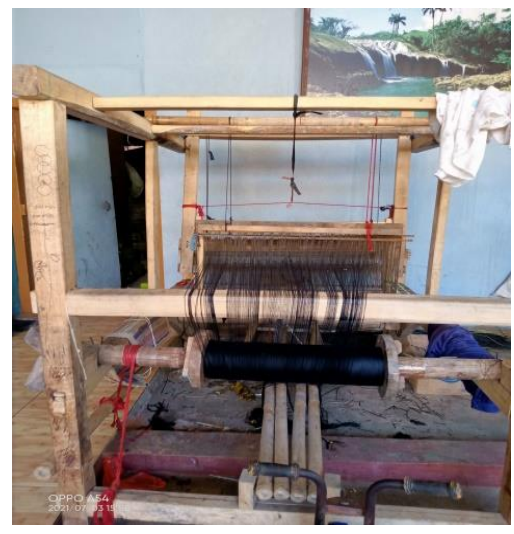

Gambar 5. Proses Pembuatan Motif Songket

Proses selanjutnya yaitu pembentukan pola Songket, pada dasarnya pola Songket akan terbentuk dari suatu penerapan tempat benang yang ada pada sisir dengan injakan 4 (lihat Gambar 5). Karena proses penyusunan benang akan mempengaruhi keindahan pada tikar. Untuk proses pembentukannya disini pengrajin menggunakan rumus pengulangan, pengulangan yang di lakukan dalam pola Songket ini yaitu 1234 (sebanyak 2 kali) 4321 (sebanyak 2 kali) dan seterusnya sampai membentuk pola belah ketupat. Pola 1234 itu artinya pengrajin pertama menginjak injakan yang ada di ATBM injakan pertama, kedua, ketiga, dan keempat (membentuk pola Songket sebelah kanan atas) dan pola 1234 lagi (membentuk pola Songket sebelak kiri atas) setelah itu ke hitungan mundur yaitu ke injakan yang keempat terlebih dahulu sampai ke injakan pertama (membentuk pola Songket sebelah kanan bawah) dan pola 4321 lagi (membentuk pola Songket sebelah kiri bawah) dan seterusnya sampai membentuk beberapa belah ketupat atau pola Songket.

Konsep estetika matematis pada anyaman mendong motif Songket ini dapat ditemukan pada struktur, bentuk dan pola anyamannya. Ada beberapa konsep matematika yang berkaitan dengan estetika hasil karya, diantaranya garis, bangun datar (pola dan geometris) dan ukuran.

Bagian pertama yaitu garis. Motif yang dibentuk melahirkan garis-garis yang membentuk sebuah objek. Garis terbentuk dari sebuah titik yang bergerak satu posisi ke posisi yang lainnya sehingga manjadi sebuah dimensi. Garis hanya mempunyai satu dimensi yaitu panjang [17]. Apabila 
dilihat dari sebuah konsep matematikanya anyaman mendong motif Songket ini memiliki konsep garis sejajar. Berikut ini adalah ilustrasi garis sejajar pada motif Songket.

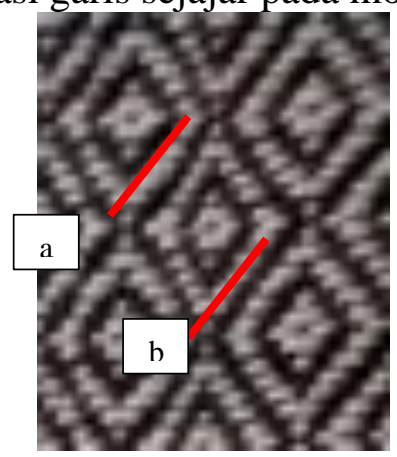

Gambar 6. Konsep Garis Sejajar Pada Anyaman Mendong Motif Songket

Konsep garis sejajar muncul akibat dari pewarnaan mendong yang beraturan menyerupai garis. Dapat dilihat pada garis A dan B garis tersebut berwarna hitam akibat pola anyaman mendong yang menumpang dan menindih dengan benang sehingga membentuk garis. Dengan menumpuk mendong dan benang atau bisa disebut menganyam, bagian-bagian tertumpuk terlihat ada sebuah hubungan. Bagian-bagian tersebut yang tertumpuk akan menciptakan sebuah objek yang baru yakni garis. Apabila dilihat dari segi estetikanya hal ini disebut dengan overlaping. Garis A dan B disebut sejajar karena apabila garis tersebut ditarik atau diperpanjang dari kanan atau kiri, garis A dan B tidak akan bertemu atau berpotongan satu sama lain. Hal teserbut selaras dengan penelitian Ayu et al [20] bahwa pada anyaman bambu ounai memiliki konsep garis sejajar yang mana apabila diilustrasikan garis tersebut walaupun diperpanjang tidak akan saling bertemu.

Bagian kedua ialah bentuk bangun datar (lihat gambar 7). Bentuk adalah garis yang menutupi suatu area, mengacu pada kontur sebuah garis, garis paling luar sebuah bidang, atau batas dari massa atau volume tiga dimensi [21]. Bentuk memiliki berbagai macam makna tergantung kepada bentuk tersebut seperti apa. Semakin sederhana dan teratur suatu bentuk dasar, maka akan semakin mudah untuk dipahami. Bentuk tersebut dapat dikaitkan dengan bangun datar pada konsep matematika dikehidupan sehari-hari. Konsep geometris pada anyaman mendong motif Songket dapat diidentifikasi dari bentuk motif dan pola yang dibentuk. Berikut adalah ilusttrasi bentuk pada anyaman mendong motif Songket.

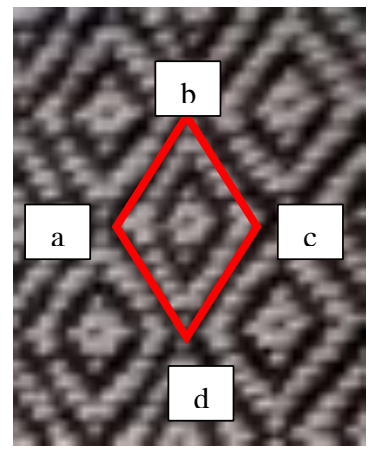

Gambar 7. Konsep Bangun Datar Pada Anyaman Mendong Motif Songket

Menurut organisasi estetika cara sederhana untuk membuat bentuk-bentuk saling berhubungan adalah dengan membuat bentuk satu dengan lainnya saling berbatasan (abutting), berbatasan sisi, sudut. Tiap bentuk saling menyentuh. Dimana mereka bertemu, saling berbagi sudut atau pinggiran. Garis-garis yang bertemu terlihat menjadi satu. Hal tersebut menciptakan ilusi bahwa bentuk-bentuk saling menempel [17]. Bentuk dapat memiliki dua atau tiga dimensi. Dua dimensi permukaannya benar-benar datar. Bentukan yang lebih kompleks, seperti persegi panjang dengan berbagai perbandingan, segi empat, poligon, dan bentuk-bentuk melengkung, teratur dan tidak teratur semua 
memiliki baik manfaat praktis dan kualitas visual ekspresif bervariasi. Bentuk bangun datar pada anyaman motif Songket yang tersebentuk adalah belah ketupat. Hal ini sejalan dengan penelitian Ibrahim et al [2] mngungkapkan bahwa dalam kerajinan anyaman Sukabumi terdapat bentuk-bentuk bangun matematika seperti lingkaran, persegi dan lain-lain.

Akibat dari pembentukan pola dari hasil menganyam mendong dengan benang menggunakan ATBM (Alat tenun Bukan Mesin) injakan 4. Untuk proses pembentukannya pengrajin menggunakan konsep pengulangan (barisan berulang), pengulangan yang di lakukan dalam pola Songket ini yaitu 1234 (sebanyak 2 kali) 4321 (sebanyak 2 kali) dan seterusnya sampai membentuk pola belah ketupat. Pola 1234 itu artinya pengrajin pertama menginjak injakan yang ada di ATBM injakan yang pertama, kedua, ketiga, dan keempat (membentuk pola Songket sebelah kanan atas) dan pola 1234 lagi (membentuk pola Songket sebelak kiri atas) setelah itu ke hitungan mundur yaitu ke injakan yang keempat terlebih dahulu sampai ke injakan pertama (memebntuk pola Songket sebelah kanan bawah) dan pola 4321 lagi (membentuk pola Songket sebelah kiri bawah) dan seterusnya sampai membentuk beberapa belah ketupat atau pola Songket.

Apabila dilihat pada gambar 7 antar garis saling bertemu sehingga membentuk suatu sudut. Sudut A akan sama besar dengan sudut $\mathrm{C}$ membentuk sudut tumpul. Begitu pula dengan sudut $\mathrm{B}$ akan sama besar dengan sudut D membentuk sudut lancip. Belah ketupat memiliki semua panjang sisi sama dan kedua diagonalnya saling berpotongan tegak lurus. Hal tersebut relevan dengan penelitian yang telah dilakukan oleh Hidayat [9] menyatakan bahwa pola-pola yang terbentuk dari anyaman mendong Manonjaya adalah pola cucuk belut dasar. Pola tersebut penjabarannya adalah 1-3-2-4-2-31-4-2-3-1-3-2-4. Injakan 4 dan dengan pola injakan 12341234. Motif Cucuk Belut Sederhana menghasilkan berbentuk segitiga yang artinya kesederhanaan.

Selain bentuk bangu datar hasil karya anyaman mendong dengan motif Songket memiliki konsep matematis refleksi. Refleksi adalah konsep transformasi geometri yang berpa perpindahan posisi suatu objek ke posisi bayangan hasil pencerminan dengn jarak yang sama. Berikut adalah ilustrasi refleksi pada anyaman mendong motif Songket.

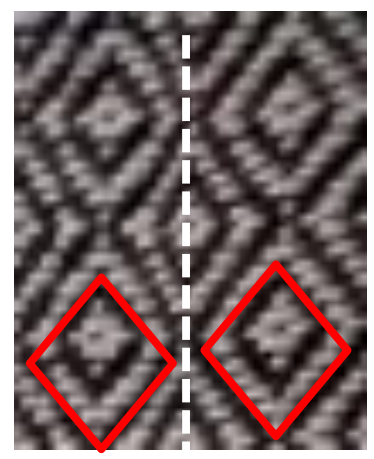

Gambar 8. Konsep refleksi Pada Anyaman Mendong Motif Songket

Pada gambar 8 Konsep refleksi atau pencerminan yang mana apabila dibagi dengan garis lurus bentuk dibagian satu dengan yang lain bentuknya sama. Selain bentuknya sama, jarak antara cermin, objek nyata dengan bayangan adalah sama.

Bagian ketiga yakni ukuran. Kaitannya matematika dengan keindahan pada motif Songket ini adalah ukuran belah ketupat yang sama dan repetisi. Cara yang cukup luas untuk mencapai unity adalah repetisi. Repetisi berarti "digunakan Iagi“. diulang. Hampir semua elemen desain dapat diulang seperti: garis. bentuk, tekstur. warna, arah atau sudut, ukuran dari bentuk atau garis. dan sebagainya [17]. Ilustrasinya disajikan pada Gambar 9. 


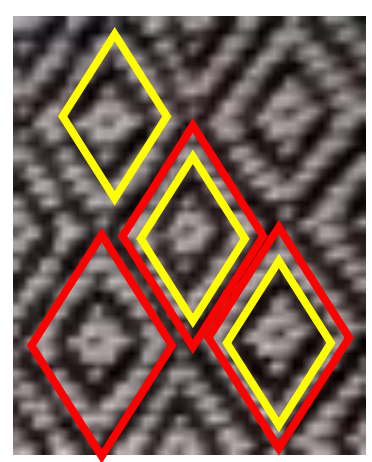

Gambar 9. ilustrasi ukuran Pada Anyaman Mendong Motif Songket

Konsep matematis yang sesuai dengan teori estetika repetisi adalah kekongruenan. Dapat dilihat dari belah ketupat yang berwarna merah ukurannya sama dengan belah ketupat warna merah yang lainnya. Untuk belah ketupat berwana kuning juga sama dengan belah ketupatberwarna kuning lainnya. Ukurannya pun sama dan dan bentuk repetisinya indah dilihat. Dalam geometri, dua bangun datar atau objek disebut saling kongruen apabila keduanya memiliki bentuk atau ukuran yang sama.

Apabila melihat ukuran belah ketupat kuning dan merah disana ada konsep kesebangunan. Kesebangunan adalah bangun datar dengan sudut-sudut yang sama besar namun ukurannya memiliki perbandingan yang sama. Hubungan kekongruenan dan kesebangunan bisa dihubungkan dengan proporsi. Proporsi menyangkut kepantasan atau hubungan harmonis satu bagian dengan bagian lainnya atau dengan dengan bagian keseluruhan, atau antara satu obyek dan obyek lainnya [21]. Proporsi ideal ini mendefinisikan hubungan yang unik antara dua bagian yang tidak sama dari satu kesatuan di mana rasio antara bagian yang kecil dan yang besar adalah sama dengan rasio dari bagian yang besar terhadap keseluruhannya.

Penelitian pada anyaman mendong motif Songket Tasikmalaya menyatakan bahwa terdapat hubungan antara nilai estetika dan konsep matematika yang membentuk motif mendong menjadi sebuah asil karya yang sarat akan keindahannya. Motif Songket pada anyaman mendong Tasikmalaya merupak realisasi konsep matematika terstruktur dan menghasilkan sebuah karya manusia yang memiliki nilai estetika. Hal tersebut relevan dengan penelitian Nur et al [6] bahwa terdapat hubungan filosofi, konsep matematika dan nilai estetika pada seni ukir Jepara yang tidak dapat dipisahkan dan menjadi satu kesatuan. Hasil dari penelitian ini sangat bermanfaat untuk kegiatan pembelajaran matematika bermakna di sekolah.

\section{Kesimpulan}

Kajian estetika matematis terdapat pada anyaman mendong motif Songket yang terdiri teori Thomas Aquines yakni Integrity or Perfection, yaitu keutuhan, kesempurnaan, atau keadaan yg menunjukkan kesatuan yangg utuh dan lengkap segalanya serta tidak cacat maupun bercela; Proportion or Harmony, yaitu perimbangan, perbandingan atau keserasian; dan Brightness or Clarity (Kecemerlangan atau Kejelasan), yaitu berwarna cemerlang atau terang. Bentuk barang dari hasil menganyam memuat konsep matematika geometri. Pola Songket atau pola gemoteris adanya unsur matematika yaitu berupa pola bilangan barisan aritmatika berulang yang adan pada motif Songket yaitu: 1, 2, 3, 4 (sebanyak 2 kali) kemudian 4, 3, 2, 1(Sebanyak 2 kali). Konsep matematis seperti pola yang berulang 1-2-3-4 dan 4-3-2-1, konsep geometris seeprti garis sejajar, pencerminan (refleksi), kekongruenan, dan bentuk bangun datar belah ketupat.

Bagi guru pelajaran matematika diharapkan agar hasil dari penelitian ini dapat menambah wawasan serta menjadi referensi untuk meningkatkan dan maengimplementasikan pembelajaran matematika estetika dan budaya. Penelitian ini terbatas hanya dari nilai estetika dan konsep matematis dari anyaman mendong motif songket. Harapannya penelitian ini berkembang dengan melihat dari segi filosofi atau semiotikanya. 


\section{Referensi}

[1] M. Royani and W. Agustina, "Bentuk-bentuk geometris pada pola kerajinan anyaman sebagai kearifan lokal di kabupaten Barito Kuala," Math Didact. J. Pendidik. Mat., vol. 3, no. 2, pp. 105-112, 2018, doi: 10.33654/math.v3i2.60.

[2] N. S. W. Ibrahim, “Analisis Etnomatematika Pada Kerajinan Anyaman Bambu Terhadap Pemebelajaran Matematika di Kabupaten Sukabumi," J. Peka, vol. 4, no. 2, pp. 35-40, 2021, doi: 10.37150/jp.v4i2.819.

[3] K. B. B. Indonesia, "Menganyam," Badan Pengembangan dan Pembinaan Bahasa, Kementerian Pendidikan, Kebudayaan, Riset, dan Teknologi Republik Indonesia, 2016. https://kbbi.kemdikbud.go.id/entri/menganyam.

[4] D. Muhtadi, R. Charitas, and I. Prahmana, "Sundanese Ethnomathematics: Mathematical Activities In Estimating, Measuring, and Making,”vol. 8, no. 2, pp. 185-198, 2017.

[5] R. S. D. Thomas, "Beauty is not all there is to Aesthetics in Mathematics †," vol. 25, no. 1, pp. 116-127, 2016.

[6] R. Nur, F. Utami, and D. Muhtadi, "Estetika Matematis Seni Ukir Jepara,” 2021.

[7] A. L. Tilaar, "Efektivitas Pembelajaran Kontekstual dalam Mengajarkan Matematika," Form. J. Ilm. Pendidik. MIPA, vol. 1, no. 3, pp. 186-191, 2015, doi: 10.30998/formatif.v1i3.72.

[8] R. Y. Gazali, "PEMBELAJARAN MATEMATIKA YANG BERMAKNA," Math Didact. J. Pendidik. Mat., vol. 2, no. 3, pp. 181-190, 2016, [Online]. Available: https://media.neliti.com/media/publications/176892-ID-pembelajaran-matematika-yangbermakna.pdf.

[9] E. Hidayat, A. G. Resfaty, and I. Muzdalipah, "Stu di etnomatematika : mengung kap gagas an dan pol a geometris pada kerajinan anyam an mendong di manonj aya kabupaten tasikmalaya," J. Authentic Res. Math. Educ., vol. 1, no. 1, pp. 19-26, 2019.

[10] L. Dietiker, A. Brakoniecki, A. S. Richman, and E. R. Miller, "Curriculum and Related Factors 66," pp. 66-73, 2016.

[11] A. Meier, M. Hannula, and M. Toivanen, "Mathematics and outdoor photography experience exploration of an approach to mathematical education, based on the theory of Dewey's aesthetics Research questions."

[12] L. G. The, Garis Besar Estetik (Filsafat Keindahan). Yogyakarta: Karya, 1975.

[13] L. G. The, Filsafat Keindahan. Yogyakarta: Pusat Belajar Ilmu Berguna, 2004.

[14] S. R. Muslim, "Eksplorasi Etnomatematika Dari Para Pengrajin Payung Geulis Tasikmalaya Jawa Barat," no. 2009, pp. 1270-1285, 2019.

[15] Z. A. Achmad, "Etnografi Virtual sebagai teknik pengumpulan data dan metode penelitian," $J$. Soc. media, vol. 2, no. 2, pp. 130-145, 2018.

[16] J. . Creswell, Research Design: Pendekatan Kualitatif, Kuantitatif dan Mixed Edisi Ketiga (Terjemahan). Yogyakarta: Pustaka Pelajar, 2010.

[17] J. Rosadi, P. Studi, D. Interior, U. K. Petra, and J. Siwalankerto, "Kajian Estetika Thomas Aquinas Pada Interior Kayu Aga House di Canggu Bali," vol. 1, no. 1, pp. 1-11, 2013.

[18] M. N. Prabawati, "Etnomatematika Masyarakat Pengrajin Anyaman Rajapolah Kabupaten Tasikmalaya," Infin. J., vol. 5, no. 1, p. 25, 2016, doi: 10.22460/infinity.v5i1.p25-31.

[19] I. Ishar, "Pengertian estetika terlengkap beserta unsur dan manfaat," 2016. https://qomaruna.com/pengertian-estetika/\#: :text=Pengertian estetika menurut Thomas 
Aquinas,merasakan suatu kesenangan setelah melihatnya.

[20] G. Ayu, A. Hartoyo, and A. Nursangaji, "Study Etnomatematika Pada Aktivitas Pengrajin Anyaman Bambu Masyarakat Sejangkung," J. Pendidik. Dan Pembelajaran Khatulistiwa, vol. 9, no. 9, pp. 1-8, 2020.

[21] F. D. K. Ching, “Arsitektur: Bentuk, Ruang, dan Tatanan,” in Trans. Hanggan Sitomorang, 3rd ed., Jakarta: Erlangga, 1996. 